\title{
Pemuridan Warga Gereja dalam Membentuk Penatalayanan Gereja Misi di BCM Ipoh - Perak
}

\author{
Joni Manumpak Parulian Gultom ${ }^{*}$, Timotius Togatorop ${ }^{2}$, Candra Gunawan \\ Simanjuntak $^{3}$, Alexander Djuang Papay ${ }^{4}$, Daniel Agustin ${ }^{5}$, Irfan Feriando Simanjuntak ${ }^{6}$ \\ 1, 2, 3, 4, 6 Prodi Teologi, STT Real Batam \\ 5 Prodi PAK, STT REAL Batam \\ *jonimanumpakgultom@gmail.com
}

\begin{abstract}
The stewardship of mission churches abroad is urgent and cannot be waiting. BCM Perak as a Local Church in Malaysia stands as a form of outreach to the souls of the Indonesian Migrant Workers who work there, requiring servants of God and leaders who can be relied on them. That is related to the limited number of ministers and leaders of the local church who can speak Indonesian. However, the local congregation, mostly Indonesian workers, does not have sufficient capacity and capability to serve and lead. The local mission church lacks ministers in almost all of its existing ministries. Discipleship is a strategic step to give birth to new Christian ministers and leaders with strategies for discipleship and mentoring of local churches. So that the church does not experience service stagnation and can still be a forum for continuous congregational faith development. This research is using the descriptive qualitative method. The purpose of this paper is to provide encouragement and longing for church members to take burdened in taking part in the stewardship of the local church maximally and continuously. The results obtained are an increase in the general number of God's servants as much as $45 \%$ of the existing number by looking at the effectiveness and efficiency of stewardship in the local church.

Keywords: Stewardship, Discipleship, mentoring, church members, BCM Perak
\end{abstract}

Abstrak

Penatalayan gereja misi di luar negeri adalah sangat urgen dan tidak dapat ditunda. BCM Perak sebagai Gereja Lokal di Malaysia berdiri sebagai bentuk penjangkauan jiwa jiwa dari Tenaga Kerja Indonesia yang bekerja di sana memerlukan para pelayan Tuhan dan pemimpin pemimpin yang bisa di andalkan. Hal ini berkaitan dengan sangat terbatasnya sekali para pelayan dan pemimpin dari gereja lokal yang memang bisa berbahasa Indonesia. Namun warga gereja yang sebagian besar di isi oleh tenaga kerja Indonesia yang bekerja tidak cukup mempunyai kapasitas dan kapabilitas yang memadai untuk bisa melayani dan juga memimpin. Gereja misi lokal kekurangan pelayan Tuhan hampir diseluruh bagian penatalayan yang ada. Pemuridan adalah menjadi langkah yang strategis untuk dapat melahirkan pelayan dan pemimpin Kristen yang baru strategi pemuridan dan mentoring gereja lokal sehingga gereja tidak mengalami stagnasi pelayanan dan tetap dapat menjadi wadah untuk pembinaan iman jemaat secara kontinyu. Penelitian ini disusun dengan menggunakan metode kualitatif deskriptif. Tujuan dari paper ini adalah untuk memberikan dorongan dan kerinduan bagi warga gereja untuk terbeban dalam mengambil bagian dari penatalayanan gereja lokal secara maksimal dan terus berlangsung secara kontinyu. Hasil yang sudah dapat dilihat adalah terjadi peningkatan secara umum jumlah pelayanan Tuhan sebanyak $45 \%$ dari jumlah yang ada dengan melihat efektifitas dan efisiensi penatalayanan yang ada dalam gereja lokal.

Kata kunci: Penatalayanan, Pemuridan, Warga Gereja, BCM Perak

\section{PENDAHULUAN}

Gereja misi yang ada di negara Malaysia sudah berdiri sejak lama. Awalnya pendirian gereja ini awalnya hanya bersifat penjangkaun dan pemeliharaan iman dari tenaga kerja Indonesia. Namun tingkat kedatangan Tenaga Kerja Indonesia terus bertambah besar jumlahnya dan itu juga sangat berpengaruh kepada demografi jumlah jemaat lokal. Dengan seiringnya waktu maka penatalayanan gereja lokal menjadi begitu banyak dan besar. Diperlukan pelayan pelayan Tuhan baru dan berkualitas untuk dapat mengambil alih jam jam ibadah, pertemuan pertemuan doa, Komunitas sel dan lain lain. Untuk mempersiapkan pelayan Tuhan yang punya kapasitas baik dalam mendukung penatalayan 
seperti ini tidaklah mudah. Diperlukan pengorbanan waktu dan tenaga untuk mengajarkan segi rohani dan kapasitas lainnya. Namun keterbatasan kemamapuan dari tim penggembalaan yang notabene kebanyakan bukan orang Indonesia, segi Bahasa dan budaya namun hal yang paling besar adalah masalah waktu yang sangat sempit diakrenakan jam pekerjaan yang sangat melelahkan 12 jam perhari.

Persoalan lainnya adalah tingkat kedalaman rohani dari jemaat lokal tenaga kerja Indonesia yang bekerja disana sangat rendah. Hampir sebagian besar tidak mengenal Akitab mereka dengan baik, belum dapat berkomitmen dalam berdoa apalagi soal Ibadah seringkali dilupakan. Hal ini disebabkan dari kampung halaman mereka tidak pernah ditekankan secara benar tentang hal hal yang berbau rohani. Kehidupan religi hanya terbatas kepada datang dan beribadah ke gerja tanpa ada beban dan tanggung jawab lebih. Kekristenan yang tanpa tugas tanggung jawab dan pertumbuhan menjadi fakta yang sangat miris ada dalam gereja. Sehingga mereka tidak merasa terkoneksi dengan pelayanan dan fungsi dalam gereja lokal.

Jemaat lokal adalah anggota gereja yang menjadi tulang punggung untuk regenerasi dan perluasan penatalayanan yang ada. Tim gereja lokal mempunyai fungsi sentral dalam menetapkan pola dalam pemuridan tepat untuk warga gereja sebagai kelanjutan dalam tugas dan beban pelayanan yang alkitabiah sehingga dapat memenuhi Amanat Agung1. Hal ini sangat dibutuhkan untuk mengenal standar dan nilai nilai penting dalam penatalayanan dalam sebuah gereja dengan segala seluk beluk dan tantangannya terlebih dahulu Pemuridan dalam gereja juga adalah sebagai sebuah bentuk tanggung jawab untuk menuntaskan Amanat Agunng Tuhan Yesus Kristus. Didalamnya nyata sekali tentang bagaimana proses pertumbuhan rohani dari seorang bayi rohani menuju kedewaaan rohani seseorang. ${ }^{2}$ Proses pertumbuhan rohani warga jemaat dalam gereja lokal ini memberikan dampak signifikan kepada karakteristik dan juga kedisiplinan dalam setiap nilai rohani. Identitas murid Yesus menjadi begitu nyata dalam kehidupan sehari hari dan itu juga nampak dalam kedisplinan pertemuan ibadah serta kelas kelas Alkitab.

Demikian juga halnya dengan warga jemaat BCM Perak yang merupak anggota aktif dari gereja lokal yang di gembalakan dan dilayani. Bagaimana tim penggembalaan memberikan penekanan dan wawasan ilahi untuk tenaga kerja Indonesia yang menjadi warga jemaat gereja misi bukan saja diselamatkan dan menjadi hidup lebih rohani namun juga menjadi pribadi pribadi yang berkarakter ilahi dalam kehidupan sehari hari, menjadi pribadi yang mencerminkan kasih Kristus, cakap melayani dan menjadi calon calon pemimpin yang berkarakter baik di tengah tengah penatalayan yang berkembang. Mereka menjadi tim yang solid untuk membangun pelayanan yang berkualitas dan menjadi berkat.

Penulis ingin melihat melihat hal hal yang berkaitan dengan beberapa hal seperti Pemuridan seperti apa yang efektif untuk menjadi dasar persiapan dalam mengemban tugas dan beban penatalayanan dalam gereja misi lokal di BCM Perak? Sehingga berdasarkan hasil dari rumusan masalh ini maka tujuan penelitian untuk memeberikan nilai nilai dan mentalitas yang sesungguhnya serta menumbuhkan kapasitas dan kapabilitas warga jemaat untuk dapat mengambil bagian dalam penatalayanan yang bertanggung jawab samapi kepada tugas yang tertingg dalam gereja lokal.

\section{METODE}

Penelitian yang dilakukan adalah menggunakan metode kualitatif deskriptif dengan menyelidiki dan berusaha menggambarkan kejadian kejadian empris di lapangan. Pengambilan data untuk penelitian ini lewat study literature dan juga observasi partisipan Ada beberapa hal yang

\footnotetext{
${ }^{1}$ Tri Subekti, "Pemuridan Misioner Dalam Menyiapkan Perluasan Gereja Lokal," EPIGRAPHE: Jurnal Teologi dan Pelayanan Kristiani 3, no. 2 (2019): 157.

2 I Putu Ayub Darmawan, "Jadikanlah Murid : Tugas Pemuridan Gereja Menurut Matius 28:18-20," Evangelical 3, no. 2 (2019): 144-153.
} 
menjadi kekuatan dalam pengambilan metode ini yaitu lebih detail dalam mengumpulkan data dan analisa serta dalam studi kepustakaan yang ada. Dan hal penting lainnya adalah sifat ex post facto, dimana hasil penelitian ini masih bisa digunakan untuk waktu waktu yang akan datang ${ }^{3}$. Sedangkan data observasi dilakukan secara partisipan, dimana peneliti melihat pembagian kelompok kelompok yang ada dan pembagian suku atau budaya di mana peneliti juga berkaitan dan berhubungan langsung dengan jemaat lokal yang ada ${ }^{4}$.

Untuk mendapatkan pemahaman yang lebih akurat maka peneliti mengamati secara langsung di lapangan sehingga dapat merasakan, mendengar dan mendapatkan respon positif dari berbagai sumber yang dijadikan data. Sasaran utama nya adalah jemaat lokal dari BCM Perak yang letak gereja nya ada di tiga lokasi yang berbeda di Ipoh. Dengan melaksanakan penelitian bersama dengan team, maka didapatkan umpan balik yang sangat dinamis dari penilaian penilaian yang ada. Hal ini memberikan impuls yang beragam namun saling melengkapi untuk mendapatkan poin penting untuk mendapatkan bahan dan materi yang mendesak untuk dijadikan acuan dalam pelaksanaan pemuridan yang ada.

Kelas pemuridan ini sendiri dilakukan dalam ruang lingkup gereja lokal yang ada di Ipoh secara bergantian di tiga tempat yang berbeda. Kelas pemuridan ini direncanakan dan dilaksanakan secara bertahap dari tanggal 4 Juni 2018 - 05 Desember 2019.

\section{HASIL DAN PEMBAHASAN}

\section{Pemuridan Warga Gereja sebagai bentuk Pendalaman Alkitab}

Warga jemaat tidak semuanya mempunyai latar belakang kerohanian yang cukup dalam dengan Alkitab. Pengenalan dan pengetahuan mereka kebanyakan sangat minim. Mereka terbiasa dengan pola gereja lama yang tidak menekankan pengenalan Firman dan kebenaran secara bertahap. Hal ini telah terjadi mungkin dalam waktu yang sangat lama dan diteruskan oleh banyak generasi dibawahnya. Akhirnya gereja sukar untuk mengalami pertumbuhan iman dan kedisiplinan. Oleh sebab itu tujuan awal dari pemuridan adalah untuk memberikan kepada warga jemaat tentang kebenaran Firman Tuhan yang mendasar dan hakiki. Hal ini menjadi tindakan yang sentral dalam setiap gereja yang ada di atas bumi dan menjadi kewajiban untuk setiap Gembala dan pemimpin gereja untuk melakukannya. Pemuridan menjadi bagian inti dari Amanat Agung Tuhan Yesus untuk menjadikan setiap orang mengenal pribadi Allah dengan benar dan sungguh sungguh

Pendalaman Alkitat BCM Ipoh dilakuakan dengan membagi kepada kelas kelas yang berlainan dengan modul modul yang diperlukan. Hal ini berkaitan dengan tingkat rohani seseorang. Hal yang menjadi analisa dasar penentuan kelas adalah sudah baptis dan pelayanan atau belum. Pendalaman Alkitab ini berhubungan dengan yang menjadi kebutuhan dasar dari warga gereja untuk dapat mengerti dan memahami dasar dasar kekristenan secara benar dan terarah. Beberapa hal yang menjadi pokok pembahasan yang sangat diperlukan adalah tentang pokok pokok keselamatan, kehidupan baru dalam Tuhan, Kehidupan pelayanan pribadi dan pengenalan dasar tentang eskatologis. Hal ini dapat dijadikan langkah awal untuk menetukan kelas mana yang harus menjadi prioritas namun diusahakan untuk berurutan dan berkesinambungan. Dari kelas kelas ini diharapkan lahir pemimpin dan pelayan Tuhan baru dengan penuh tanggung jawab dan integritas yang tinggi ${ }^{5}$.

Dalam setiap kegiatan kelas disertai dengan Pujian dan Penyembahan, dan diskusi. Diharapkan kelas ini tidak melupakan hubungan pribadi dengan Tuhan dan juga memberikan kesempatan untuk saling bertukar pikiran atau sharing tentang Firman Tuhan. Tidak dipungkiri bahwa kemampuan jemaat dalam kelas berbeda-beda, namun saling melengkapi dan diberikan kesempatan untuk mengembangkan diri secara bertahap. Sebagai bentuk tanggung jawab jemaat dalam kelas dan juga memonitor tingkat pengertian dan pemahaman mereka tentang bahan yang sudah diajarkan, maka $105-113$.

${ }^{3}$ Baso Intang Sappaile, "Konsep Penelitian Ex-Post Facto," Pendidikan Matematika 1, no. 2 (2010):

${ }^{4}$ Hasyim Hasanah, “Teknik-Teknik Observasi,” at-Taqaddum 8, no. 1 (2016): 21-46.

5 Agus Prihanto, "Peran Proses Mentoring Pemimpin Kaum Muda Bagi Perkembangan Pelayanan Pemuda Di Gereja,” Jurnal Jaffray 16, no. 2 (2018): 197. 
dberikan tugas yang sederhana sebagai bentuk refleksi pendalaman Alkitab dalam aplikasi kehidupan sehari hari. Hal ini untuk mendorong warga jemaat menjadi pelayan Tuhan yang efektif sesuai dengan keadaan mereka masing masing sehingga dapat mengalami pertumbuhan yang signifikan ${ }^{6}$.

Sebagai pengajar dan murid dalam kelas pendalaman Alkitab harus terjalain keakraban dan kasih. Kelas hendaknya penuh dengan suasana ilahi, bukan hanya sekedar perpindahan narasi atau cerita. Jemaat BCM Perak juga diajarkan untuk dapat menghadirkan suasana Sorga dalam kehangatan kasih di setiap kelas yang diadakan. Teknik yang digunakan adalah nilai kebersamaan dan kekeluargaan menjadi bagian penting dalam komunikasi dan interaksi satu dengan lainnya. Ada kesaksian yang hidup dan juga sharing dari pengalaman firman dalam diskusi yang hangat dan menggairahkan.

\section{Pemuridan Warga Gereja sebagai bentuk kelas Kepemimpinan}

Dalam kelas pemuridan BCM Perak ini juga dijadikan sebagai proyek untuk melihat pelayan pelayan Tuhan dan calon pemimpin dalam pelayanan di masa datang. Kelas ini harus mampu untuk memberikan kesempatan kepada setiap jemaat dalam menunjukkan kepribadiannya secara nyata dan maksimal ${ }^{7}$. Alkitab menyatakan tentang 12 murid Yesus yang adalah para nelayan sederhana dan tidak berpendidikan tinggi namun menjadi sasaran dan target Yesus untuk dijadikan sebagai Rasul Rasul dikemudian hari meneruskan pelayanan Ilahi kepada jiwa jiwa sampai ujung bumi (Kisah 1:8 ; Matius 28 “ 18-20). Pemuridan untuk menjadikan jemaat BCM Perak menjadi pemimpin adaah dengan metode memberikan kepaa merekabahan tentang tanggung jawab kekristenan seperti Misi, Bersaksi, Pujian dan Penyembahan dan juga membangun kehidupan pribadi yang kuat. Jemaat BCM Perak yang ikut dalam kelas pemuridan harus ambil bagian dalam pelayanan baik itu bersifat pribadi ataupun pelayanan bersama sama sebagai bentuk pelayanan dalam gereja. Hal ini akan memberikan motivasi dan pendorong untuk bertanggung jawab secara penuh kepada tugas masing masing dari tingkat yang paling sederhana. Hal ini merujuk kepada kasus penurunan kepemimpinan gereja yang ada dikarenakan karena jemaat tidak punya tanggung jawab moral kepada Tuhan dan sesama untuk melayani dengan komitmen yang tinggi ${ }^{8}$.
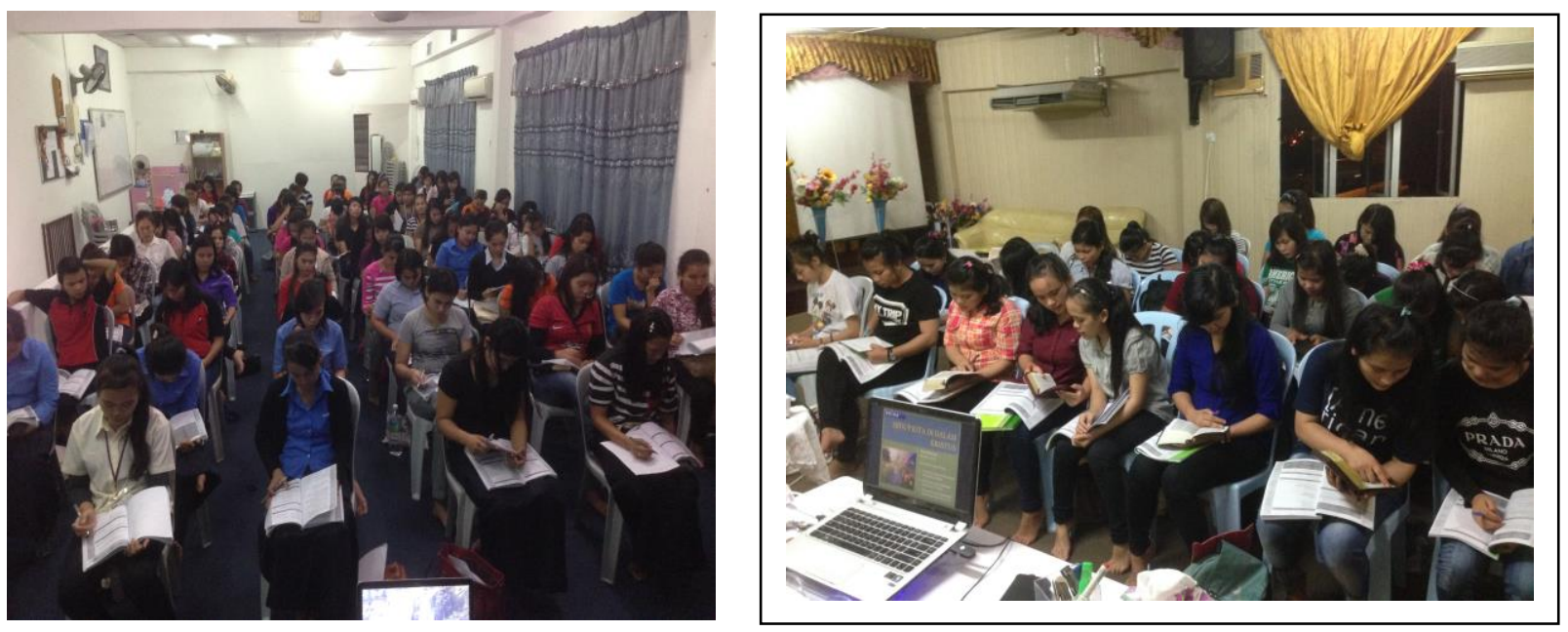

Gambar 1. Kegiatan dalam kelas Pemuridan

Gereja lokal BCM Perak melalui kelas ini dapat memberikan banyak panggung pelayanan untuk jemaat keas pemuridan. Memberikan kepada mereka motivasi dan doa serta kekuatan untuk dapat mengambil tugas pelayanan yang sederhana yang mereka biasa buat. Gereja lokal harus mempercayakan pelayanan pelayanan tertentu kepada mereka untuk memulainya. Tentu aka nada banyak keterbatasn ataupun kesalahan kesalahan pada tahap awal. Namun sebagai bentuk praktek dari

${ }^{6}$ Junihot M. Simanjuntak, “Belajar Sebagai Identitas Dan Tugas Gereja,” Jurnal Jaffray 16, no. 1 (2018): 1

${ }^{7}$ Darmawan, “Jadikanlah Murid : Tugas Pemuridan Gereja Menurut Matius 28:18-20.” Gereja."

${ }^{8}$ Prihanto, "Peran Proses Mentoring Pemimpin Kaum Muda Bagi Perkembangan Pelayanan Pemuda Di 
kelas pemuridan ini maka akan di hasilkan calon pemimpin baru di masa yang akan datang. Contoh sederhana adalah para pendoa, para pemuji pemyembah, para pengkotbah dan para penginjil. Hal ini menjadi kesinambungan yang terjalin dengan baik antara kelas pemuridan yang diadakan dengan gereja lokal BCM Perak yang menaungi.

\section{SIMPULAN}

Kegiatan pemuridan yang dilakukan untuk BCM Perak ini telah dilakukan dengan baik dan sesuai dengan rencana sebagai bentuk pengabdian masyarakat. Lewat kegiatan ini didapatkan beberapa hal penting sebagai acuan dan juga evaluasi. Hal yang bisa di lihat adalah 1) Pemuridan ini menjadi jantung pelayanan terpenting dari setiap gereja lokal yang ada di atas bumi, dimana gereja lokal yang hanya berfokus kepada hal lahiriah seperti jumlah jemaat dan gedung maka satu saat mengalami masalah dengan regenerasi dan pelayanan yang tidak pernah mengalami peningkatan significan. 2) Pemuridan ini menjadi pembinaan warga gereja untuk mengalami pertumbuhan secara rohani dan dewasa dalam iman. Bagaimana mereka datang ke gereja bukan untuk hanya dapatkan berkat namun punya beban dan tanggung jawab ilahi dalam kegiatan sehari hari. 3) Jemaat Lokal menjadi sumber daya yang samapai hari belum tereksplore dengan maksimal dan terus memerlukan strategi yang memadai, pendanaan yang besar serta waktu yang cukup panjang. Namun keberhasilan dari pemuridan jemaat lokal ini pada akhirnya dapat menutupi seluruh kekuatiran dan ketakutan dari gereja lokal akan itu semua, dikarenakan tingkata kerohanian yang bertumbuh telah merikan kontribusi kedisplinan dan tanggung jawab yang permanen. Mereka menjadi penggerak penggerak yang meneruskan tugas pelayanan dan panggilan gereja yang efektif dan efisien baik dalam keluarga, komunitas bahkan samapi ke generasi berikutnya.

\section{DAFTAR PUSTAKA}

Darmawan, I Putu Ayub. "Jadikanlah Murid : Tugas Pemuridan Gereja Menurut Matius 28:18-20." Evangelical 3, no. 2 (2019): 144-153.

Hasanah, Hasyim. "Teknik-Teknik Observasi." at-Taqaddum 8, no. 1 (2016): 21-46.

Prihanto, Agus. "Peran Proses Mentoring Pemimpin Kaum Muda Bagi Perkembangan Pelayanan Pemuda Di Gereja." Jurnal Jaffray 16, no. 2 (2018): 197.

Sappaile, Baso Intang. "Konsep Penelitian Ex-Post Facto." Pendidikan Matematika 1, no. 2 (2010): 105-113.

Simanjuntak, Junihot M. "Belajar Sebagai Identitas Dan Tugas Gereja.” Jurnal Jaffray 16, no. 1 (2018): 1.

Subekti, Tri. "Pemuridan Misioner Dalam Menyiapkan Perluasan Gereja Lokal." EPIGRAPHE: Jurnal Teologi dan Pelayanan Kristiani 3, no. 2 (2019): 157. 